\title{
NEW STUDENT ADMISSIONS INFORMATION SYSTEM WITH CLIENT SERVER BASED SMS GATEWAY
}

\author{
Zulhipni Reno Saputra Elsi ${ }^{*}$; Gita Rohana²; Vera Nuranjani ${ }^{3}$ \\ Teknologi Informasi ${ }^{1,2,3}$ \\ Universitas Muhammadiyah Palembang \\ www.um-palembang.ac.id
}

zulhipni_renosaputra@um-palembang.ac.id,gitarohana306@gmail.com,veranuranjani2016@gmail.com

(*) Corresponding Author

\begin{abstract}
Palembang State Junior High School 58 every year accepts new students, every year SMP N 58 always uses the form in registration and collects diplomas, SKHUN, and other files in hardcopy format so that they often experience file loss for that we need a new student admission information system based client-server and SMS gateway. This information system was designed using the Software Development Life Cycle (SDLC) method, and an analysis and design were carried out using a Data Flow Diagram. This information system has the function of saving, delete, update, report automatically, and can send information in the form of SMS. The new student admission information system is user friendly so that it can be easily used, so the admission process is more effective and there are no more missing files.
\end{abstract}

Keywords: New Student Admission; Information System, SMS Gateway; Software Development Life Cycle.

Intisari-Sekolah Menengah Pertama Negeri 58 Palembang setiap tahun melakukan penerimaan siswa baru, setiap tahun SMP N 58 selalu menggunakan formulir dalam pendaftaran dan mengumpulkan ijazah, SKHUN dan berkas lainya dalam bentuk hardcopy sehingga sering mengalami kehilangan berkas untuk itu diperlukan sebuah sistem informasi penerimaan siswa baru yang berbasis client server dan sms gateway. Sistem informasi ini dirancang dengan menggunakan metode Software Development life Cycle (SDLC), serta dilakukan analisa dan perancangan dengan Data Flow Diagram. Sistem informasi ini mempunyai fungsi simpan, hapus, update, laporan automatis, serta dapat mengirim informasi berupa SMS. Sistem informasi penerimaan siswa baru bersifat user friendly sehingga dapat dengan mudah digunakan, sehingga proses penerimaan siswa baru lebih efektif dan tidak adanya lagi berkas berkas yang hilang..

Kata Kunci: Sistem Informasi; Penerimaan Siswa Baru SMS Gateway;Software Development Life Cycle.

\section{INTRODUCTION}

With the rapid development of technology, the new student registration process should be done anywhere and anytime, for example at home, outside the city, and no longer need to come to school to queue up for forms[1] and the payment process can be done online[2].

In the research, Umi Kholifah said that the implementation of the New Student Admissions
Information System provides time efficiency in the processing of new student admissions[3]. Currently, computer-based data processing has developed rapidly, the use of computer programs is very helpful for its users to solve difficult problems so that data processing can be done well besides that it also has high accuracy so that it will make it easier and not take time. long time searching for the required data.

Table 1. Previous Research

\begin{tabular}{|c|c|c|c|c|}
\hline NO & NAME & PROBLEM & METHOD & RESULT \\
\hline 1 & $\begin{array}{l}\text { Wahyu Hidayat, } \\
\text { Ramadhian Agus } \\
\text { Triono, Sukadi } \\
\text { Pembangunan } \\
\text { Sistem Informasi } \\
\text { Pendaftaran Siswa } \\
\text { Baru SMP Negeri } 2 \\
\text { Sudimoro Pacitan }\end{array}$ & $\begin{array}{l}\text { Data collection for new } \\
\text { student registration at } \\
\text { SMPN } 2 \text { Sudimoro Pacitan } \\
\text { is done conventionally. }\end{array}$ & $\begin{array}{l}\text { Designed using } \\
\text { context diagrams }\end{array}$ & $\begin{array}{l}\text { With this new student registration } \\
\text { information system, the PSB committee } \\
\text { can accelerate the process of recording } \\
\text { student data, reducing mistakes in } \\
\text { recording and losing data[4]. }\end{array}$ \\
\hline
\end{tabular}




\begin{tabular}{|c|c|c|c|c|}
\hline NO & NAME & PROBLEM & METHOD & RESULT \\
\hline 2 & $\begin{array}{l}\text { Santoso } \\
\text { Sistem Informasi } \\
\text { Pendaftaran Siswa } \\
\text { Baru Pada SMK } \\
\text { Diponegoro } \\
\text { Tulakan }\end{array}$ & $\begin{array}{l}\text { The system in processing } \\
\text { new student data at SMK } \\
\text { Diponegoro has not been } \\
\text { computerized }\end{array}$ & $\begin{array}{l}\text { Make observations of } \\
\text { the object being } \\
\text { observed then } \\
\text { perform problem- } \\
\text { solving analysis }\end{array}$ & $\begin{array}{l}\text { With the new student registration } \\
\text { information system that uses the } \\
\text { Microsoft Visual Basic } 6.0 \text { programming } \\
\text { language, data processing of new student } \\
\text { candidates becomes easier and more } \\
\text { efficient[5]. }\end{array}$ \\
\hline 3 & $\begin{array}{l}\text { Fajar Sidik, Mari } \\
\text { Rahmawati } \\
\text { Perancangan } \\
\text { Sistem Informasi } \\
\text { Pendaftaran Siswa } \\
\text { Baru Berbasis Web } \\
\text { Pada SMK Bina } \\
\text { Putra Jakarta }\end{array}$ & $\begin{array}{l}\text { The registration system is } \\
\text { still offline, uses paper, } \\
\text { which results in queues } \\
\text { when registering, and risks } \\
\text { losing data }\end{array}$ & Waterfall method & $\begin{array}{l}\text { The existence of an online information } \\
\text { system reduces paper usage and does not } \\
\text { occur data loss so that queues do not } \\
\text { occur when registering[6]. }\end{array}$ \\
\hline
\end{tabular}

Based on table 1, it can be concluded that the problems that exist in schools at the time of admission of new students are the systems that still use paper in the registration process and new student data collection and this problem can be overcome by developing a new student admission information system even though using different methods.

Junior High School (SMP) Negeri 58 Palembang was established on June 23, 2014. SMP Negeri 58 Palembang every year will accept new students (PSB), in this PSB process PSB officers are still managing registration data and admission of prospective new students still using the media paper for registration.

In the first process, prospective students are required to fill out a registration form and submit the required documents, such as diploma, SKHUN, and others to the PSB committee. After the registration form and required documents are received by the PSB committee, then the forms and documents are verified. If the required forms and documents are declared complete, the PSB committee will record the registration of prospective students in the registration book as well as provide details of education payments. In the next stage, prospective students are required to make educational payments to the PSB committee after receiving details of education payments [7].

When students return the registration files to the PSB committee and the registration files for new prospective students are still kept in an archive, so they are vulnerable to file loss and damage because too many students register[8]. Then the PSB committee recaps into the computer in the process of data recording the committee using Microsoft Excel[9].

Currently, SMPN 58 Palembang requires proper data processing to create efficiency and accuracy of data to support operational processes, management, and decision-making processes properly. With the above problems, it is necessary to improve the system that is running, for that we need a client-based application. Server and SMS Gateway to simplify the PSB process.

\section{MATERIALS AND METHODS}

This research refers to the research framework described in Figure 1.

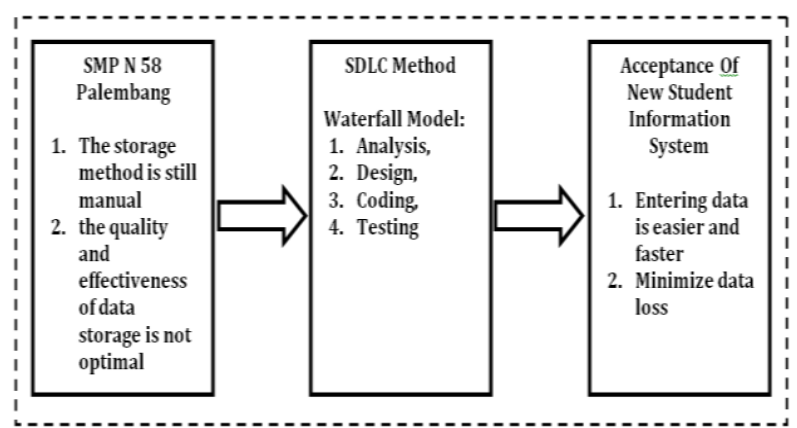

Figure 1. Research Framework

In Figure 1, the stages carried out in research where SMP Negeri 58 Palembang have 2 problems. The problem is that the system developer uses the SDLC method with the waterfall model and finally produces a new information system.

In the development of this information system, research data was collected, the research data were obtained by two methods, namely:

1) Interview

Researchers conducted direct interviews with the principal of SMPN 58 Palembang and the head of administration at SMP N 58 Palembang, where the results of the interview revealed the procedures for new student admissions, input, and data reports of new students that had been running at SMPN 58 Palembang.

2) Observation

Observation is data collection carried out by direct observation of the object of research[10]. Researchers made observations at SMPN 58 Palembang, by directly surveying how new student data input and new student data reports. The 
results of observations made by the author at SMPN 58 Palembang are examples of registration forms that have been filled in by new student candidates submitted to the new student admissions committee or administrative staff at SMPN 58 Palembang then selected according to the requirements for new student admission then announced on the school walls After that, the student data received is recapitulated to a computer using the Microsft Excel application, wherein Microsoft Excel, not all new student data is entered, this is due to time efficiency in the processing process.

In this study, the system was developed using the Software Development Life Cycle (SDLC) method. The stages in this study refer to the Waterfall model stages, namely analysis, design, coding, testing, and maintenance [11] [1][12][13].

\section{A. Needs Analysis}

Data input is a process of entering the relevant data into one place (in this case software) with the aim that the data is not lost and can be reopened. For example, at SMPN 58 Palembang, this government agency engaged in education uses Microsoft Excel software. In entering data for new students at SMPN 58 Palembang, the administrative staff who served as the entry committee were found to be obstacles, the extent to which the data was lost, and also the ineffective time used to enter the data.

This new student admission application is designed to help overcome problems faced by the committee or new admissions staff when inputting and reporting new student data at SMPN 58 Palembang. The general function of this application design is to input new student data, in this new student admission application is equipped with edit, cancel, search, save, delete, and print facilities.

\section{B. Design}

The design is part of the Waterfall model stage, this stage is carried out after the analysis stage. At this stage, it provides a detailed description. In system design, the system design that will be built is described before coding into a programming language [4].

Figure 2 illustrates the data flow used during data processing, the data flow is drawn with a Data Flow Diagram. Data Flow Diagrams are a way to document the design system process to show the flow of information and information transformation applied as data flowing from input and output[3][14].

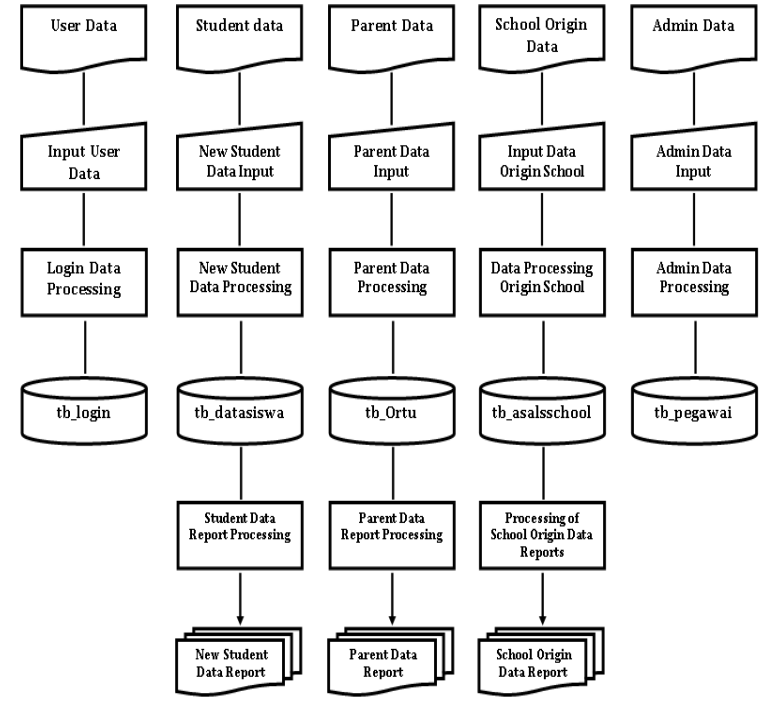

Figure 2. Flow Chart

Use case new student information system is depicted in the diagram in Figure 3.

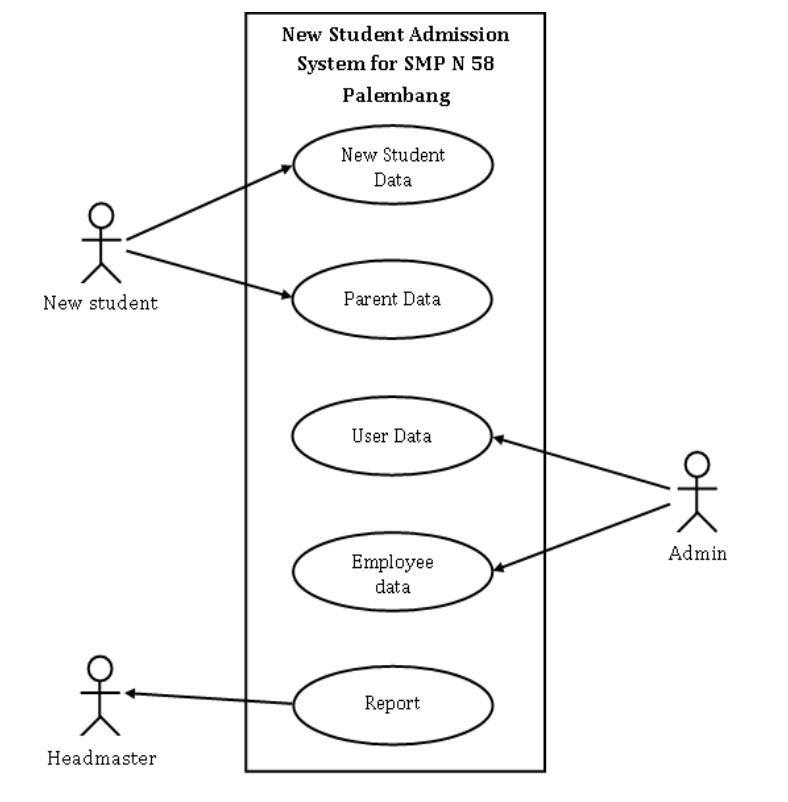

Figure 3. Uses case

Figure 3 explains those who play a role in using the information system, namely the admin (committee), the principal, and new students.

\section{Encoding}

At this stage, the preparation or writing of the Delphi programming language is carried out according to the system design that has been made so that it becomes the required information system. The Client-Server Information System topology is depicted in Figure 4. 


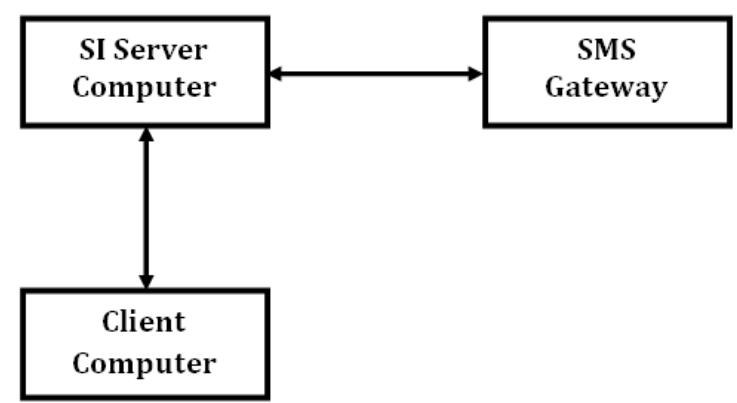

Figure 4. Client-Server Information System Topology

Figure 4 shows the client-server topology, the information system used consists of a server computer connected to the SMS gateway and a server computer connected to the client computer.

\section{Testing}

At this stage, testing is carried out on a system that has been completed using a network with two computers, with one computer being used as a server and the other as a client. This testing system uses the User Accepted Test (UAT) method with the UAT type Black Box Testing. Black Box Testing is functionality testing, where the enduser will test the function of the software regardless of the internal code structure.

\section{RESULTS AND DISCUSSION}

The results of the design of a new admissions information system with data flow diagrams can be implemented in the system. Implementation is the steps or procedures carried out in completing an approved system design, to test, install, and start a new system or a repaired system to replace the old system.

The dashboard for the new student admission information system only has the login and CANCEL menu, on this menu application users who want to open the information system must first $\log$ in to be able to the main information system dashboard.

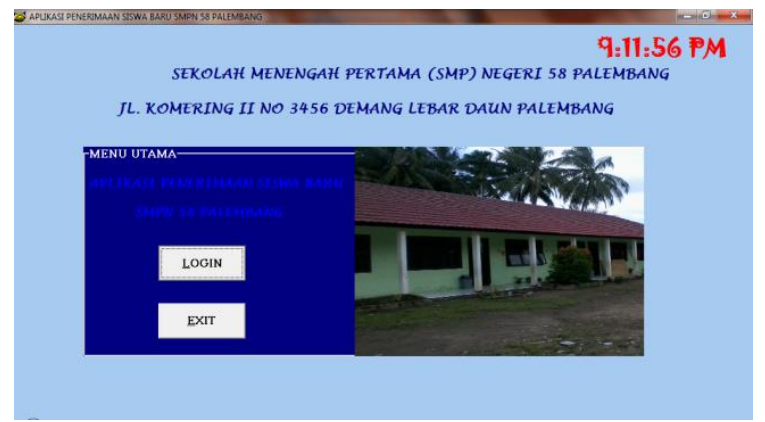

Figure 5. Information System Dashboard

Figure 5 shows the information system dashboard, there are only log in and Exit buttons.
After the user logs in, the main dashboard will appear as depicted in Figure 6.

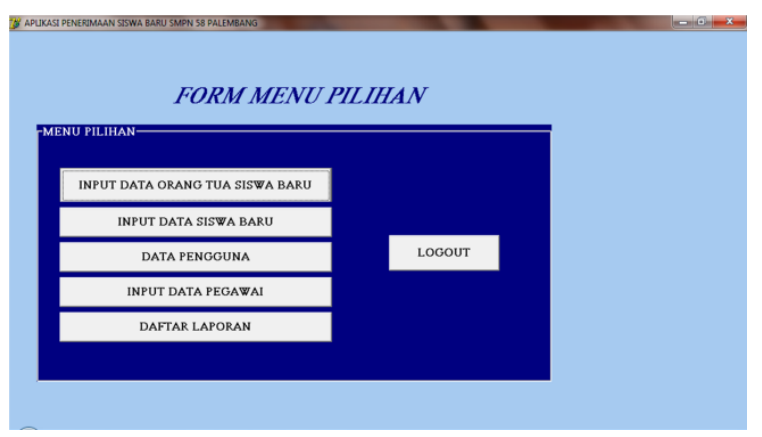

Figure 6. Main Dashboard of Information Systems

In Figure 66 buttons can be used by users, these 5 buttons can call the new student-parent data input menu function, new student data input, user data, employee data input, report list, and 1 button to exit.

The new student data form is used to input data related to new students such as NIS, NISN, student name, address, date of birth, and some others. In this form there is a menu for the process of saving, editing, exiting, deleting, refreshing, adding, printing, and also searching for data. The image of the new student data input form can be seen in Figure 7.

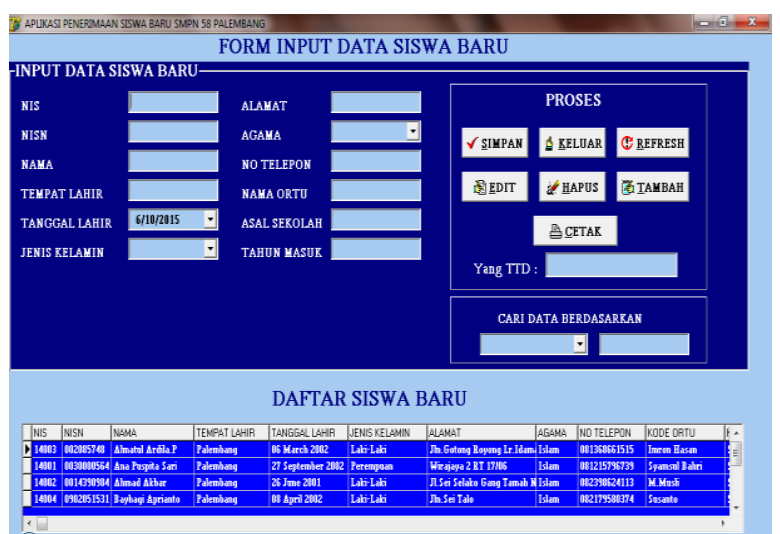

Figure 7. New Student Data Form

The process of filling in the new student data input form by filling in each textbox on the form, after all the textboxes are filled, new student data can be saved after saving by clicking the SAVE button.

After all the data is stored, the data will enter into the dBGrid and immediately provide an SMS notification to the new students that the data attached is complete. The SMS notification can be seen in Figure 8. 
JITK (JURNAL ILMU PENGETAHUAN

DAN TEKNOLOGI KOMPUTER

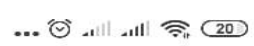

$+6281808204163$

Indonesia

1. $9: 32$

Selamat Bergabung di SMP N 58

Palembang.

Nama : Khairunisa Zahraa

Kelas : 7-2

Untuk Informasi terbaru Silahkan

datang ke SMP N 58 atau IG

SMPN58PLG

Figure 8. SMS notification

The parent data form is used to input data related to the parents of new students such as the name of the father, mother, occupation, address, and NISN. In this form there is a menu for the process of saving, editing, exiting, deleting, refreshing, adding, printing, and also searching for data. The image of the new student parents' data input form can be seen in Figure 9.

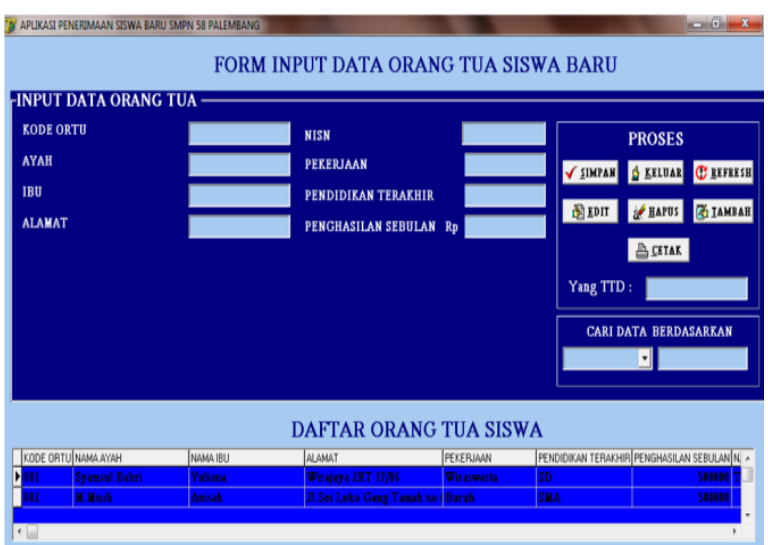

Figure 9. Parent Data Form

The employee data form is used to input data related to employees such as id, name, gender, place of birth, date of birth, and position. In this form there is a menu for the save, edit, out, delete, refresh, and add processes. The image of the employee data input form can be seen in Figure 10.

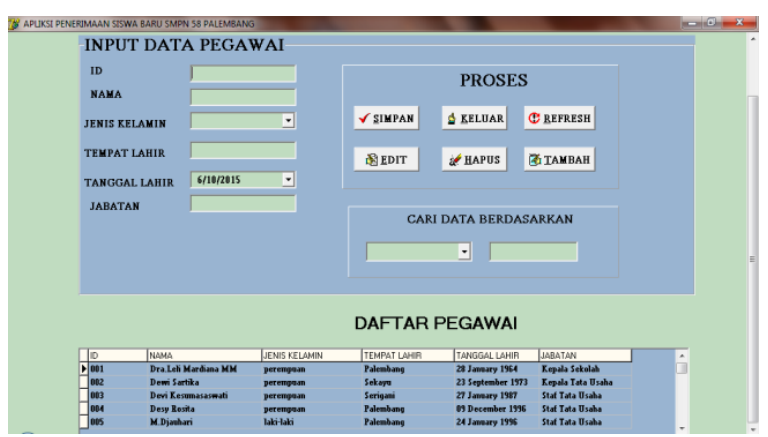

Figure 10. Employee Data Form
VOL. 6. NO. 2 FEBRUARY 2021

P-ISSN: 2685-8223 | E-ISSN: 2527-4864

DOI: $10.33480 / j i t k . v 6 i 2.1377$

A user data form is for inputting user data such as admin and user, as for inputted data such as name, password, position, and status. The image of the user data form can be seen in Figure 11.

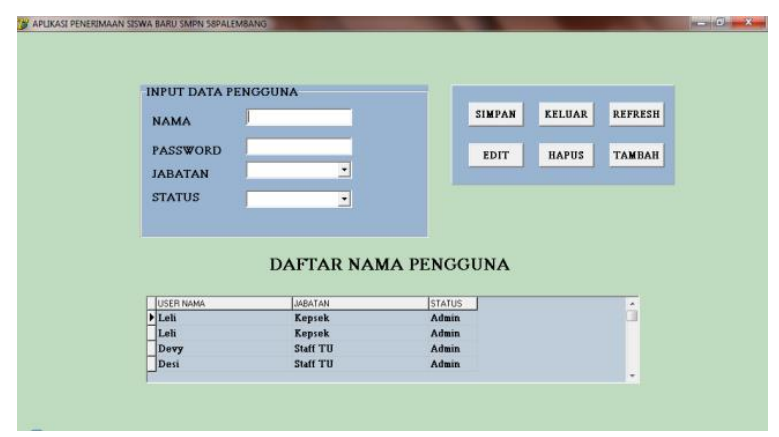

Figure 11. User Data Form

In Figure 11 there is a combo box status, this combo box functions for users of the new student admission information system.

In this report menu, the admin and user can select a list of reports such as new student data reports, new student parents data reports, new student school data reports, student data reports based on the year of entry, and student data reports by gender. The menu display can be seen in Figure 12.

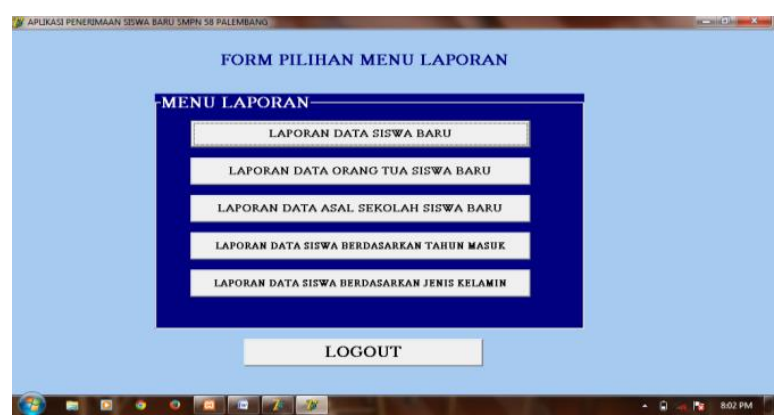

Figure 12. SI report

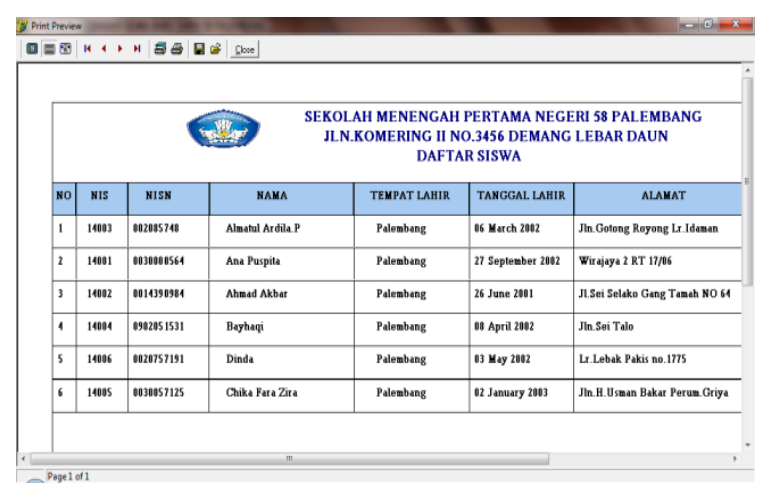

Figure 13. New Student Report

Figure 13 shows the new student admission report form based on new student data. 


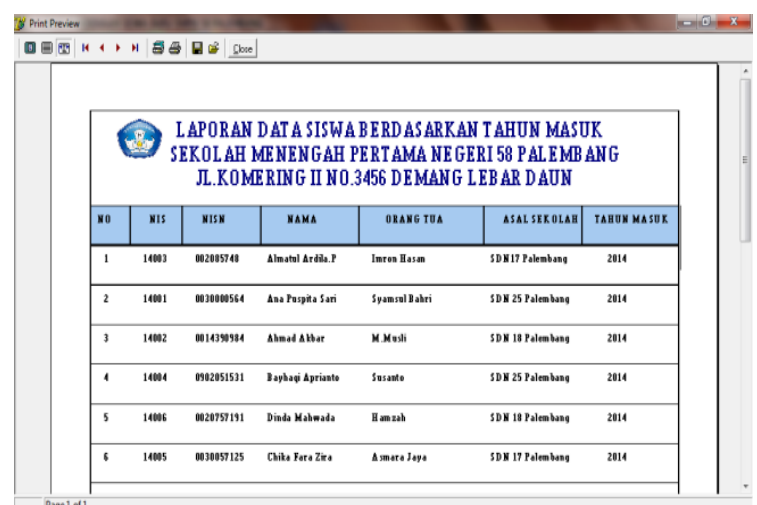

Figure 14. Report of New Students with School of Origin

Figure 14 shows the new student admission report form based on the student's school of origin.

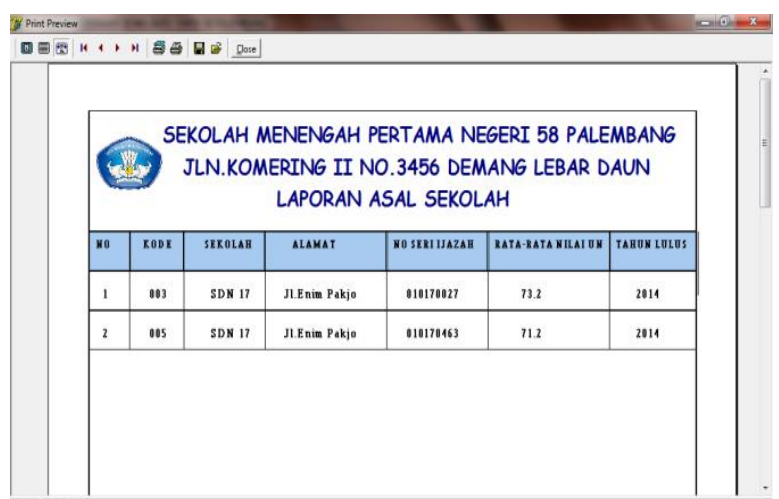

Figure 15. Report of New Student School Origin Data

Whereas Figure 15 shows the school data report based on the origin of the new student's school.

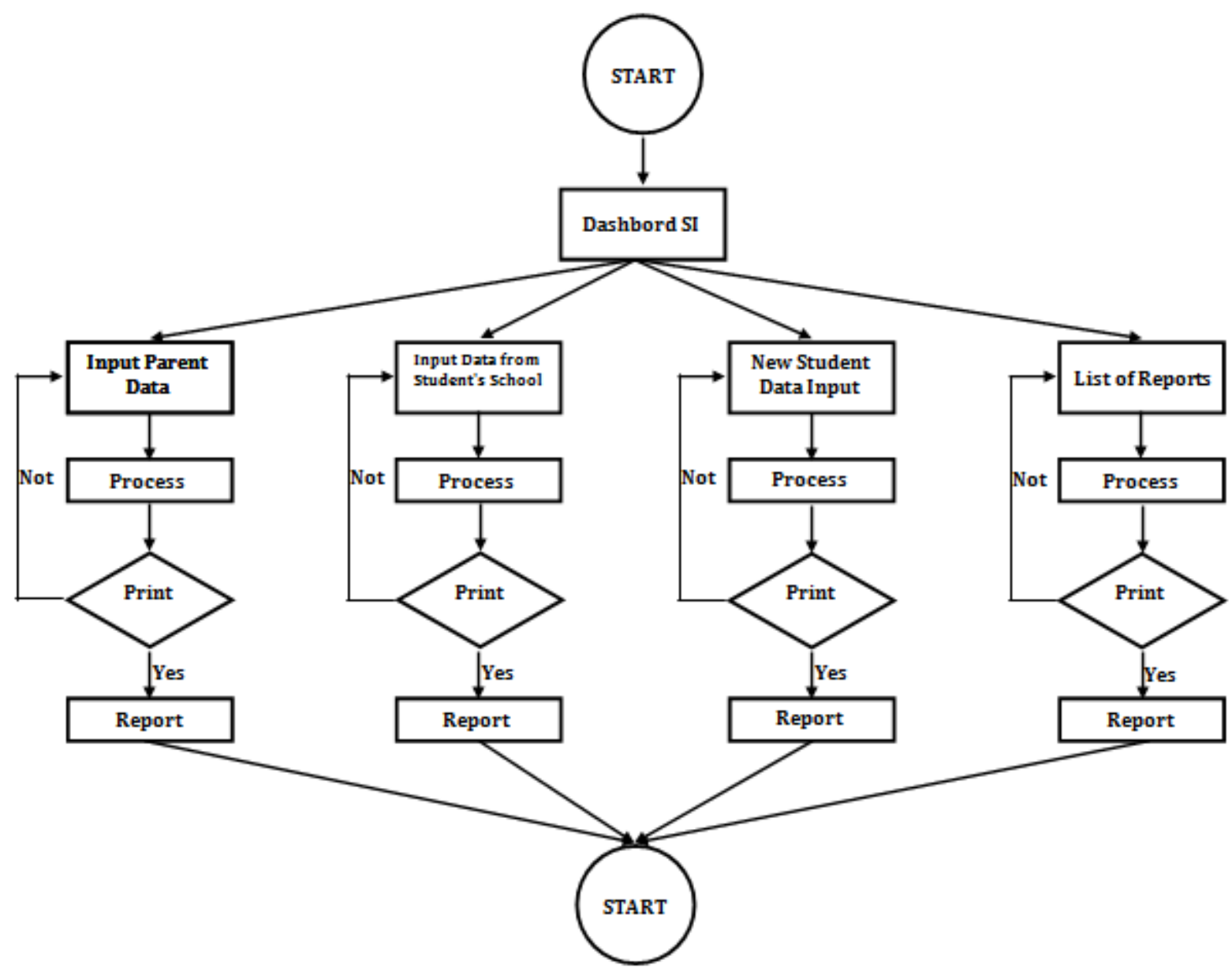

Figure 16. Flowchart of new student admission information system

Figure 16 illustrates the flowchart of the use of the new student admissions information system starting with a star then processed, in this first process 6 processes can be used. Of these 6 processes, there are 4 processes, while the other 2 processes have no reports.
To test the information system that has been created, information system testing is carried out using a server computer, an SMS gateway, and a server computer. Based on the testing that has been done, the results are: 
a. Data processing can run better, all data inputted can be stored in the database.

b. The new admissions information system is user friendly.

c. The process of creating reports relating to new students can be done quickly.

From the results of testing the information system for new student admissions, there are advantages and disadvantages, including:

1) Advantage

In the data entry process, it is younger, because it uses a database so that the process of searching for data and storing data is younger and safer. The new student admission information system can create new student reports, new student parent data reports, and new student school data reports.

2) Loss

In this new student admission application, it is still limited to internal, where only the school can input and see, external or external parties cannot because it is not online yet.

The test results with Black Box Testing can be seen in Table 1 below.

Table 1. Black box testing success percentage

\begin{tabular}{lcccc}
\hline \multicolumn{1}{c}{ Menu } & $\begin{array}{c}\text { Successful } \\
(\%)\end{array}$ & $\begin{array}{c}\text { Failed } \\
(\%)\end{array}$ & $\begin{array}{c}\text { Timed } \\
\text { Out } \\
(\%)\end{array}$ & $\begin{array}{c}\text { Not } \\
\text { Played } \\
(\%)\end{array}$ \\
\hline New Student Data & 98.76 & 0.44 & 0.62 & 0.18 \\
Parent Data & 99.01 & 0.38 & 0.42 & 0.19 \\
User Data & 99.63 & 0.24 & 0.13 & 0 \\
Employee data & 98.96 & 0.57 & 0.36 & 0.11 \\
Report & 99.84 & 0.08 & 0.08 & 0 \\
\hline Total & 99.24 & 0.342 & 0.322 & 0.096 \\
\hline
\end{tabular}

\section{CONCLUSION}

Successfully creating a new student admission system based on client-server and SMS gateway at SMP Negeri 58 Palembang, this information system can input new student data, new student parents data, user data, employee data, and reports. The report is related to data entry so that the new student data processing information system can help new student data entry at SMPN 58 Palembang more effectively and new students can receive information via SMS. Based on the results of the UAT test, the acceptance rate of this new student admission system is on average 99.24 percent, the failure of this system is on average 0.342 percent, Timed Out is on average 0.322 and Not Played is on average 0.096 .

\section{REFERENCE}

[1] Sunarti, "Implementasi Sistem Informasi Penerimaan Siswa Baru," J. Evolusi - Vol. 3 No 2 - 2015 - Ippm3.bsi.ac.id/jurnal, 2015.

[2] Jimmie, M. I. Ma'ruf, and D. Mahendra, "Sistem Informasi Penerimaan Siswa Baru Berbasis Web Di Sekolah Menengah Pertama Negeri 43 Palembang," J. Digit. Teknol. Inf., vol. 1, no. 2, pp. 98-105, 2018.

[3] I. U. W. Umi Kholifah, "Sistem Informasi Pendaftaran Peserta Didik Baru Pada Sekolah Menengah Kejuruan Negeri 1 Sudimoro," IJNS - Indones. J. Netw. Secur., 2014, doi: 10.1123/IJNS.V3I3.1254.

[4] W. Hidayat, R. A. Triono, and Sukadi, "Pembangunan Sistem Informasi Pendaftaran Siswa Baru Smp Negeri 2 Sudimoro Pacitan," IJNS - Indones. J. Netw. Secur., vol. 4, no. 3, pp. 1-6, 2013.

[5] Santoso, "Sistem Informasi Pendaftaran Siswa Baru Pada SMK Diponegoro Tulakan," J. Speed - Sentra Penelit. Eng. dan Edukasi, vol. 7, no. 1, pp. 46-52, 2015.

F. Sidik and M. Rahmawati, "Perancangan Sistem Informasi Pendaftaran Siswa Baru Berbasis Web Pada SMK Bina Putra Jakarta," Paradigma, vol. 20, no. 1, pp. 119128, 2018.

[7] Ruhul Amin, "Rancang Bangun Sistem Informasi Penerimaan Siswa Baru Pada SMK Budhi Warman 1 Jakarta," J. ILMU Pengetah. DAN Teknol. Komput., vol. 2, no. 2, pp. 113-121, 2017.

[8] S. Suherni, N. Rubiati, and H. Khumaini, "Aplikasi Pendaftaran Dan Penerimaan Siswa Baru Di Smk Negeri 1 Rupat Berbasis Web Dan SMS Gateway," J. Inform. Manaj. dan Komput., vol. 9, no. 2, pp. 15-24.

[9] D. A. Wasesha, "Implementasi Metodologi Waterfall Dalam Sistem Pendukung Keputusan Penyedia Informasi Akademik Universitas," INTI Nusa Mandiri, vol. 14, no. 1, pp. 41-48, 2019.

[10] D. Haryanto and Apriansyah, "Kesiapan Industri Kelapa Sawit Dalam Implementasi Enterprise Resource Planning," J. Teknol. Inf. Mura, vol. 12, no. 1, pp. 29-43, 2020. 
[11] R. Febryan, R. I. Euclerr, Y. Wardaningsih, and F. Masya, "Web-Based Event Seminar Registration Information System Application," J. Ris. Inform., vol. 2, no. 3, pp. 159-168, Jun. 2020, DOI: 10.34288/jri.v2i3.144.

[12] S. Shofia and D. A. Anggoro, "Sistem Informasi Manajemen Administrasi Dan Keuangan Pada Tk-It Permata Hati Sumberrejo-Bojonegoro," J. ILMU Pengetah. DAN Teknol. Komput., vol. 5, no. 1, pp. 221-
$230,2020$.

[13] Karnadi and T. Ismail, "Sistem Informasi Penerimaan Siswa Baru Berbasis Web Di SMA Muhammadiyah 1 Muara Padang," J. Digit. Teknol. Inf., vol. 1, no. 2, pp. 56-63, 2018.

[14] Ermatita, "Analisis Dan Perancangan Sistem Informasi Perpustakaan," J. Sist. Inf., vol. 8, no. 1 , pp. 966-977, 2016. 